\title{
"POVERTY AND BRILLIANCE OF TRANSLATION": THE PHENOMENON OF LACUNARITY IN IBERIC PHILOLOGY AND ITS TRANSLATION (BASED ON THE TRANSLATION OF THE COMIC "THE FATE OF NUMANCIA" FROM SPANISH INTO RUSSIAN)
}

\author{
Anna Khodorenko ${ }^{1}$
}

\begin{abstract}
The article deals with the general problems of the translation of lacunar units in the translation of the work, "The Fate of the Numantia" from Spanish to Russian, connected with the phenomenon of lacunarity, using functional, comparative methods, as well as the method of contextual analysis of inter-language and structural-semantic comparison of lacunar units. The paper contributes the study of the inter-semiotic translation of comic books by means of a descriptive analysis of the translation of the comic "Numantia" and peculiar characteristics of Spanish-Russian translation with pragmatic functions focused. The study is carried out through an effective analysis of the two languages and their relations while translation the comic book in Russian. This work dealing with the peculiarities of intersemiotic translation could facilitate the clarification of the original text of other kinds of translation such as interlinguistic or intralinguistic translation. The intention of the work is, therefore, to study the main characteristics of the comic with the help and by means of corpus, of the two main languages and the relations between them. Main translation transformations have been identified and classified with the examples shown. The concepts of onomatopoeia, lacunarity, metaphor have been discussed.
\end{abstract}

\section{Keywords}

Lacunarity, nomination, semantics, lexical substitution, syntactical replacement.

1. Introduction. Since recently, it has been observed a great evolution in the course of the study of comics resulted from the great demand of the public interest and the necessity to translate comic texts. However, the study of its translation as a form of intersemiotic translation has not been contemplated. Since this field has not been explored, our work aims to contribute to the study of intersemiotic translation in comics, particularly, the comic "The fate of Numantia".

Thus, establishing relationships between the information transmitted in the comic (text and image) and the translation is supposed to be of great importance while working with the type of comic texts and can be helpful in the process of translating comics. Also, the comics that we are dealing with are of a certain theme: the historic one. Here we can find a lot of symbology that will also influence the transmission of information in this medium and the use of the non-verbal channel. Therefore, the present work consists of an analysis of the comic and its use to transmit a historic message (related to the legendary fight of guarders) of Numancia in which attention will be paid to the two channels from the that the information is issued. We take into account the historic symbols in general, those we find in this comic to see its density and importance within the language of the comic.

Our objective is to identify the relationship between two channels of transmitting message in the

\footnotetext{
${ }^{1}$ Khodorenko Anna, DSc, professor, Dnipro Oles' Honchar National University, Gagarin av. 72, 49000-Dnipro, Ukraine, E-mail:khodorenko_anna@ua.fm
}

comic and find out the prevalence between them. The task is supposed to be done while analyzing the elements and particular characteristics of each one. It is of interest the study of them because they will depend on the reception and understanding of the message by the public and the translation of the text into Russian.

For this, initially we will make a theoretical approach with which we will review the pillars of this study: the comic as a type of text and its characteristics, the relationship with translation and the intersemiotic relationship with the Numancia and, especially, with the figures of Warriors of Numancia.

The aims of the paper are: 1 . Study the comic as a form of subordinate translation. 2. Study the semiotic relationship present in the comics of the Numancia. The specific objectives are specified below. 1. Establish relationships between the verbal and visual language of the comics studied. Determine the main features of the comic book. Determine the concept of lacunarity and discuss the ways to solve the latter.

2. Methodology. This work follows a descriptive methodology, which starts from the observation of the facts found in the comics and the elaboration of some empirical arguments. From this observation, we will establish a series of assessments and conclusions. Attention has been focused on the in-depth analysis of a specific comic in which we will describe the elements found in each unit of analysis, which in this case will be the vignette. We will analyze the visual elements of one part and the verbal elements of another and finally establish the relationships between them. The material of the work has been selected after visiting digital libraries with available collection of 
comics. The selection of material was followed by a search for documentation to determine the relevant parameters used in the analysis of the case. Finally, the appropriate conclusions have been drawn after interpreting the general results of the descriptive analysis of each vignette, which have allowed us to have a global vision necessary for the investigation.

2.1. Research materials. The material of the research is the original Spanish comic book "The fate of Numantia" written by R. Garcia ("El destino de Numancia") and its translation into Russian suggested by me personally (the translation has not been published yet).

2.2. Methods of analysis. Methods of analysis combine those of experimental and qualitative research methods. Translation models and methods of translations are discussed with the examples filtered to illustrate the most problematic places while translating the comic book. The work uses functional, comparative methods, as well as a method of contextual analysis of interlingual and structural-semantic comparison of lacunary units.

\section{Results and Discussion.}

3.1. Theoretical background. "It is a comic about the history of Numancia, we have scripted the story and created the characters, but it is still in the oven", commented Rubén García. The representative of Numanguerrix said that "the script is already finished and polished." "We are embodying the story in the vignettes, the story is drawn and then the entire editing process," he said. R. García ${ }^{2}$ commented that the possibility of bringing Numancia to a comic was always present since the birth of the Numanguerrix business project. The script for the comic, as Garcia explains, was born from the elaboration of a historical recreation. "We started to write the story and it got a script in short and now we decided it to be a comic, but the possibility of its developing is also there," he says.

The adventure of cómic takes place in the year 114 A.C., according to commented Garcia, that is to say, almost two decades after the fall of the celtíbera city. At that time a Roman general, Mario, visited a Numancia converted into a Roman city. The Roman general arrives in the city accompanied by a Numantian slave. According to Garcia, the history of Numancia will be present through the memories that the visit to the city arouses in the mind of the Numantian slave.

The keys that separate one theory from the other is to consider that the text is an optional element in the comics and that the balloon is a defining element of the comic. Seeing clearly the creation of the comic can be an arduous task. This is because not all authors

\footnotetext{
${ }^{2}$ Garcia, 2018

${ }^{3}$ Töpffer, 2002

${ }^{4}$ Outcault 2002

${ }^{5}$ Aparici, 1992

${ }^{6}$ Max und Moritz 1992
}

consider that the comic has the same characteristics and, as is logical, they have not reached a consensus to delimit the first text considered comic. As it has been established in the previous section, in this work we will consider comics to those stories narrated through a sequence of structured images in which the graphic and linguistic codes coexist. Therefore, we discard the idea of some authors that the first productions that could be classified within this genre are cave paintings. Although it is true that these paintings narrated a story with sequenced images, they did not involve the word. In the thematic area in which we move, religion, we find many examples of this type of communication through images (such as pictographic catechisms), but, as we will see, this is a hybrid genre, so for us the birth of the comic It happened much later.

After dismissing the proposal, we must decide between the other two reigns that do contemplate the comic as a text in which the visual and linguistic language coexist. However, one of them considers that the comic appeared only with the introduction of the sandwiches. In the seventies, this last theory was the one that got more support, unlike today, which is the minority tendency. We join the idea that the comic emerged when the word was integrated into these graphic stories without necessarily having to be within the image. For this reason, we will consider that the origin of the comic is found in the productions that arose after 1830 from the hand of Rodolphe Töpffer ${ }^{3} 1$ and not in 1886 with the introduction of the balloon in the vignettes by Richard F. Outcault ${ }^{4}$. However, the comic is the product of evolution for centuries. We could even say that its origins go back to the vignettes with a small explanation on foot of this as the hallelujahs, some historic stamps from France, or the aucas, similar but of pagan origin. This type of texts emerged in the mid-fifteenth century, a date well before the dating of the birth of the comic, and consisted of narrative strips distributed in a series of vignettes accompanied by explanatory texts at the bottom. Each vignette was a scene whose understanding was difficult if the explanatory text that accompanied it was not read. The hallelujahs, in particular, were distributed in large historic offices or processions where they received a large audience.

In 1829, Töpffer created the first "stories in images" considered to be the first comic book. Töpffer explained what this term was about: "There are two ways of writing stories, one in chapters, lines and words, and we call it literature, and another through a succession of images, and we call this" the story in images $\rangle^{5}$. It consisted of a series of stories destined to entertain the students of his boarding school in the summer period. These were not arranged in a format similar to a book, so they did not contain the vignette scene technique, and the text was separated from the image. Years later, in 1865 approximately Wilhelm Busch creates Max und Moritz ${ }^{6}$, two naughty children who became the 
first protagonists of comics. All these were the bases on which the comic was erected in Europe.

The search for a greater readership of newspapers at the end of the 19th century both in Europe and in the USA. UU was what prompted the appearance of some vignettes in the Sunday supplements.

Noticing the enormous interest aroused by comics and comic strips in newspapers, some saw an open market niche (a space and perspective) and at the beginning of the 20th century began to found large agencies in the United States that sold these products inside and outside their borders. These big agencies were shaping the model of the current comic when trying to standardize the publications and imposing a format among those that were used at that time, as it was a genre in hatching with very diverse styles.

In Spain, the current comic arrived in the early twentieth century, although during the nineteenth century there were also different publications of political or children's issues with similar characteristics. With the end of the dictatorship, comics dedicated to adults began to appear. During the transition, publishers such as La Cúpula, an example of underground comics in Spain, or El Jueves, a political satire magazine, broke with the established scheme and gave a strong boost to freedom of expression, which had previously been stifled by the censorship of the dictatorship.

The decade of the eighties also gave way to the rise of superhero comics in our country and in the nineties it was when the manga broke into the national market. The traditional comics for children like Zipi and Zape or Mortadelo and Filemón were with new and very different currents that had a lot of acceptance in our country. Finally, that same decade and the next one devoted the sequential art for adults with the appearance of the graphic novel.

3.2 Characteristics and types. The comic is a type of text with special characteristics 7 . 1. Diachronic narrative character of the message. The comic tells a succession of events that is marked by the structuring of the vignettes and their sequence. Thus, the temporal succession, apart from being able to be explicitly indicated, obeys the reading pattern from top to bottom and from right to left. 2. Convergence of verbal and iconic elements. These elements are integrated by means of cartridges (external surfaces to the image where the text is embedded), direct expression of the characters (balloon or speech bubble) and onomatopoeias (without determined representation). This combination gives it a great synthetic capacity in communication, communicating a lot with few elements. 3. Attend to a series of codes and conventions, such as the use of the previous elements, the type of bullet and other composition rules. 4 . Reach a wide spread thanks to a large number of readers attracted by this genre. 5. Its predominant function is distractive.

${ }^{7}$ Diéguez, 1977
Should it be clarified that by many scholars comic begins to be considered a means of mass communication. These characteristics synthesize very well the main features of the comics, but in addition to them we can find others that also deserve our interest, because they are very relevant to understand the art of comics. So, the comic is a mixed text that combines image and word, that uses static images presenting a story in movement. For the expression of that movement, which always presents a challenge, various techniques have been developed making the task easier for the reader, but they still require an imaginative effort to bring life to the story completely, as we must also do when reading novels or another type of literature. In addition to movement, these texts also imitate oral style and tradition, because they pretend to be a story as lively as possible catching the reader as much as cinema or television. This, perhaps, is one of the characteristics that stand out the most and give it that privileged place for its readers. On the other hand, it is a very flexible genre that lends itself to be accessible to all kinds of people, from children to the most literate. Maybe, that is why it's considered a means of mass communication. This flexibility extends from its thematic content to its presentation, composition, aesthetics and graphic resources that end up defining its style. Likewise, the external format is also flexible, since the type of binding, size and number of pages can differ in each case.

Types of comics. Comics are classified according to main factors: the theme and the target audience. There are comics of war content, police or detective, of adventures, of superheroes, of science fiction, humoristic, sports, historical, biographical, romantic, erotic, fantastic, terror, political, religious, etc. In previous sections we have highlighted that since its inception, some topics have been more popular than others, partly due to the particularities of the historical moment and that, with the development of this type of texts, the thematic repertoire has to be expanded to achieve the current great variety. Ignoring this aspect in a certain way, we can divide the comics by the public they appeal to. Generally, they are divided by age ranges of recipients: children's, youth and adult comics. However, some authors warn that it could also include the classification of comics according to the genre of their readers, because it is true that there are some that are mainly dedicated to men and others that are mainly intended to call the female audience (although this may be a more controversial issue).

3.3. Translation of the comic book. We can consider translation as a practice that converts the message from one language into another so that the recipient perceives it as the original message. Traditionally, the general public considers only the translation of the fact of the linguistic transfer of a message to a different language, however, this approach ignores 
the true nature of the translation. Translation is a phenomenon that occurs because of the need to make two interlocutors who do not share the same code understand each other. Thus, communication is the process that governs translation and this is not always limited to the verbal code. The process of communication also serves to explain semiotics, since all we use to communicate are signs. Normally, when we talk about communication, we only refer to the field of human communication, perhaps because it is the most immediate and closest to us. But, apart from human communication, there is also animal, plant and even machine communication. All these forms of communication make use of a system of signs that can be studied. In our case, we will focus on the semiotics of humans, since it is the one that intervenes in comics.

We can not forget that in communication we can distinguish between two main branches: verbal and non-verbal communication. Normally, we attribute the weight of communication to information transmitted verbally, ignoring the true power of nonverbal communication. In fact, in oral communication, the information transmitted by the verbal channel only represents $35 \%$ of the total, the rest is transmitted through the non-verbal channel, being 38\% transmitted by intonation and $27 \%{ }^{8}$ (Birdwhistell, 1952, cited in Fantini, 2017) for the corporal attitude. In fact, when we are faced with two speakers of different languages, sign communication becomes the universal language that the two interlocutors can interpret. That is how, for example, the Spaniards managed to communicate with the indigenous peoples in the conquest of America until they understood their language. We believe that one of the most suggestive ideas about these types of translation is the classification of Jakobson ${ }^{9}$ (1963: 79) in which he presents three forms of translation:

- Intralinguistic translation or reformulation: interpretation of linguistic signs by other signs of the same language.

- Interlinguistic translation or translation properly: interpretation of linguistic signs by another language.

- Intermiotic translation or transmutation: interpretation of linguistic signs by non-linguistic sign systems.

Interlinguistic translation would be the variety most commonly known when talking about the translation task. This process requires the transfer of a message from one language to another that may be very different or similar. The intralinguistic translation consists of the adaptation of a message in a language to a meta text in the same language, but with a different variety (either diphasic, diastratic or diatopic). The intersemiotic translation involves moving the message from one system of signs to an-

\footnotetext{
${ }^{8}$ Birdwhistell, 1952, Fantini, 2017

${ }^{9}$ Jakobson 1963
}

other, resulting in a code change. In this case, the translation object of our study would be mainly intersemiotic, since we will compare the information obtained by the two communication channels and we will see how the change of code has affected the meaning of the message.

On the other hand, when we face the translation of the comic, we find a more complex process than in the translation of other types of texts. This is because, by their very nature, the characteristics of these texts demand more attention and special treatment when translating them into another language. When we work with academic, scientific or legal texts, and even with literary texts, we must follow established conventions that have to do with the format and type of language used. But all information is shown by a single channel of communication or medium. On the contrary, in the comic we find two codes (visual and verbal) and between them there is also a process of semiotic translation that will influence a supposed interlinguistic translation. Hence, the translation of comics is considered a type of subordinate translation or hybrid code.

3.4. Analysis of translation. Transformations and the problem of lacunarity. The present part is to the problems of translating devoted the work "The Fate of Numancia" from Spanish to Russian, and in particular to the problems associated with the phenomenon of lacunarity. The purpose of the article is to outline in general terms the comic "The Fate of Numancia" and in general to show the lines of solving translation problems. Practical significance consists in improving the methods and methods of translation from Spanish into Russian and from Russian into Spanish, in the theory and practice of lexicography, and translation studies.

The material of the study was the comic book "The Fate of Numancia", based on real events that took place in Numancia (now Garray, Soria province, Spain) more than two thousand years ago and tells of the defenders of ancient Numancia, who suffered from the enemies, on the one hand, and those who attacked it, on the other. Ayus, one of the few survivors after the fall, slaves who fought for two decades and suffered martyrdom, tells of a 20 -year resistance to Rome. The authors R. Garcia and E. Torres reflect on their first work (one of the most epic stories in the world) with passion. Based on the real facts that took place in Numantia (currently Garray, Soria) more than two thousand years ago, this work gives a voice to all those characters who were excluded from history. Those who are not mentioned in the classical works that we can read today, which narrate the facts that shaped the myth, see their courage and their fears reflected, their glory and their miseries.

Affected by the historical characters that defended Numantia, on one side, and those who attacked it, on the other, The "Fate of Numantia. Aius" narrates the 
twenty years of Numantine resistance facing the almighty Rome from a slave's point of view, one of the few survivors of the fall of his town, but who fought for two decades and suffered the most horrible ending to his life possible.

Rubén García and Edu Torres reflect on their first work (one of the most epic stories in the world) with passion and without prejudices, but sadly, it is also one of the most ignored and unknown stories. Its repercussions were not only about to make an empire collapse, but even today we still live under the influence of some of its consequences.

The Celtiberian oppidum of Numantia was attacked more than once by Roman forces, but the Siege of Numantia refers to the culminating and pacifying action of the long-running Numantine War between the forces of the Roman Republic and those of the native population of Hispania Citerior. The Numantine War was the third of the Celtiberian Wars and it broke out in $143 \mathrm{BC}$. A decade later, in $133 \mathrm{BC}$, the Roman general and hero of the Third Punic War, Scipio Aemilianus Africanus, subjugated Numantia, the chief Celtiberian city.

In late $135 \mathrm{BC}$, the Roman Senate reappointed Scipio consul on popular demand and sent him to Hispania to finish what lesser generals had failed to complete. Scipio found morale low among the troops stationed in Iberia. The chance of plunder being low, there were few enticements to enlistment. Scipio nevertheless raised an army of 20,000 with 40,000 allied and mercenary troops, especially Numidian cavalry led by Jugurtha. The troops were trained hard by constant marching and there were several successful skirmishes before Scipio began to surround the city of Numantia itself. He planned only to starve it out and not to storm it.

Scipio's army constructed two camps separated by a wall around the city (circumvallation). He dammed the nearby swamp to create a lake between the city walls and his own. From ten feet off the ground, his archers could shoot into Numantia from seven towers interspersed along the wall. He also built an outer wall to protect his camps (eventually five in total) from any relief forces (contravallation).

Scipio also engineered the isolation of the city from the Duero. He towered the river at the points where it entered and exited the city and strung a cable across, with blades, to prevent both boats and swimmers from leaving or entering the city.

The Numantines attempted one failed sally before their greatest warrior, Rhetogenes, successfully led a small band of men down the river past the blockade. Heading first to the Arevaci, his pleas were ignored. He then went to Lutia, where he was positively received by the youth, but the elders of the tribe warned

\footnotetext{
${ }^{10}$ Gasset 1990

${ }^{11}$ Obolenskaya
}

Scipio, who marched from Numantia and arrested the 400 Lutian youths and cut off their hands. After Scipio's return, Avarus, the Numantine leader, began negotiations.

The first ambassadors sent by Numantia asked for their liberty in return for complete surrender, but Scipio refused. They were killed upon return by the incredulous populace, who believed they had cut a deal with the Romans. The city refused to surrender and starvation set in. Cannibalism ensued and eventually some began to commit suicide with their whole families. The remnant population finally surrendered only after setting their city on fire. Scipio took it and had its ruins levelled. This was late in the summer of 133 . Unfortunately, this is one of the most ignored and unknown stories. The consequences of the resistance were not only in the fall of Rome, but also in the fact that the past events of resistance of Numancia remind us of themselves until now. The significance of the work is, accordingly, the importance of the translation being performed.

Recalling E. Koseriu, V. Garcia Yebra, recognizing the Spanish Schools of Translators of the XI-XIII centuries, their contribution to the history of translation, expressing the opinion that the tradition of translation in Spain as a whole didn't appear as such. Attempts in the sphere of theoretical interpretation of translation practice fall on the second third of the twentieth century.

O. Gasset ${ }^{10}$, in the article we quote here "Poverty and the brilliance of the translation", mentioned that "readers of any country are not pleased with the translation made in the style of their own language. To do this, they have enough of the writings of their authors. They like the opposite: in order to bring the possibilities of the language to the limit of understanding, it showed through the manner of speaking peculiar to the translated author".

As indicated by Y. L. Obolenskaya", "one when making a translation from one language to another, intends to translate each time only to substitute a word with a word corresponding to him, preserving the construction of the description and the order of the words in it, one will have to work hard, in eventually getting the translation wrong and confused". This way is wrong. The translator must clarify the course of thought, then express and interpret it in such a way that the thought come clear and understandable in another language. To achieve this, you can sometimes only change all the preceding or following a word, translating one word by several or several - one, combining some statements and selecting others, so that the idea becomes absolutely clear and understandable, as if originally expressed in the language of translation. "

Thus, the task of both a translator and an interpreter becomes even more difficult, because the translator is under the Damocles Gladius (Damoclis gladius) of 
the critics, authors, as well as between two languages, two national consciousnesses, stories, cultures, perceptions. As the practice of translating the factual material of the article, namely the comic book "Numancia", shows, it is not possible to follow one of the transfer strategies mentioned above. Preserving the original translator achieves purity of thought and clarity of its transmission to the reader. In the example below, you can see the preservation of the style with a single lexical substitution of daba paso (literally "give a move") to give a way.

... De haber matado a su abuelo Balor con su honda, daba paso a la oscuridad de la noche ... - > ... After killing his grandfather Balor, he gave way to the darkness of the night ...

The systematization of the phenomenon of lacunarity in languages, in general, and the allocation of Russian lacunar units (LU) and lacunar spaniisms, the allocation of ethnographic lacunar units in the languages being compared, as well as the equivalence conditions and the adequacy of translations at the level of lacunary units of the compared languages, makes it possible to translate in accordance with theoretical rationale for achieving the ultimate goal of a successful translation result ("product").

The study of the problem of lacunarity on the example of the comic book "Numancia" made it possible to establish that the semantic discrepancy between languages is related to the specifics of the language, culture and history of nations. Lacunarity is considered as a linguistic and cultural category. The question of nonequivalence in the language of translation of lacunar formations determined the need for their direct translation and the appearance of borrowings.

According to the classifications proposed by different researchers, using the example of our material, several types were identified: (1). Lexico-semantic lacunary units; 1.1 . Historical lacunary units (proper names, geographical names). Examples: Numancia, Ayus, Segeideans. 2. Lexico-stylistic lacunary units. Phraseological units, nonequivalent fibrations. For example:

... El augur golpeó una y otra vez las vísceras del cobarde con su mano derecha y el mensaje de los dioses era claro ... -> ... again and again beat the coward's right hand ... the message of the gods was clear...

The study of ethnographic lacunarity allows us to conclude that, being in direct connection with extralinguistic reality, it is a dynamic category: lacunae can appear or disappear, fill in the language, together with the emergence of phenomena and concepts that generate them, or when the means of compensating for lacunarity become equivalents.

At the lexico-semantic level, lacunary units, -semantic archaisms, background lacunary units, emotional lacunary units, exclamations of heroes .. Structural analysis of the types of units under investigation and their translation showed, with the increase of the denotative saturation of the lacunary units value, the frequency of occurrence of interlanguage lexical lacunarity increases, due to the possession of the emotive function (the analysis is made on the example of the comics, the exclamations of the heroes are taken into account), the components of lacunarity are also related to the category of connotation.

Historical lacunary units include: 1) realities (clothing, profession, transport, housing, lacunary units with the meaning of food, dishes, household utensils, games, musical instruments, monetary units, measures of length and weight); 2) lacunary units (geographical realities, historical names, culturological realities);

Let us give some examples. For clarity, the lacunary units are highlighted and underlined.

Sabiendo que los aniquilarían, abandonaron su ciudad y huyeron hasta aquí. - $>$ Зная, что они будут уничтожены, они покинули свой город и скрылись здесь.

Gracias a su caudillo, Caros, el más belicoso de los guerreros, con buenas dotes de mando y famoso por su valor, los numantinos acogimos a su pueblo. Y no sólo sus almas, sino también sus problemas con Roma. $\rightarrow$ Благодаря своему лидеру, Каросу, самому агрессивному из воинов, с хорошими лидерскими качествами известному своей храбростью, нумантиниь приветствовали его в своей деревне. И не только народ, но и борьбу с Римом.

Así, nos convertimos en su objetivo. $\longrightarrow$ Таким образом, мы стали их иелью.

Ante esta rebelión, el senado tomó una decisión $\underline{\sin }$ precedentes. $\rightarrow$ Столкнувшись с сопротивлением, сенат принял беспречедентное решение.

Decidieron cambiar el inicio del año de los idus de marzo... $\rightarrow$ Они решили изменить начало года ...

Consideration of the means of translating lacunary units in the translation of fiction allows one to recognize the calculating, the descriptive method and the creation of correlation contexts successful. Lacunary units, as indicated, complicate the task of translation. On the one hand, the translator must disclose the meaning of the lacunary unit and convey the meaning implied by the play of words. The goal that the interpreter pursues is to fill the semantic loss of meaning conveyed by the play of words in those cases where, in our opinion, this is difficult to do. From the Spanish lacunar lexicon from the actual study material, it was determined: 1. Obsolete lacunar vocabulary: archaisms, historicisms; 2. Units of Spanish origin: lacunary units denoting customs and traditions; professions, titles; monetary units; the name of buildings, premises; the name of household items; food, beverages; clothes and their details; geographical names; the name of songs, dances, musical instruments; nicknames. 
4. Conclusions. According to the research objectives analisys of extralinguistic factors, iconic code and translation transformations made it possible to define and clarify the notion of cognitive metaphor through knowledge of the context of the work, knowledge of culture, traditions, etc. expressed by phraseologisms. The phenomenon of the equivalence of the translation of the cognitive metaphor was analyzed in general terms according to the peculiarities of the translation.

A comparative analysis has shown that the difficulties that have emerged throughout the work are due to the fact that grammatical and lexical forms are not equivalent to Russian ones. In the translation process it often becomes impossible to use the matching words and phrases provided by the dictionary. In such cases, we resort to a transformational translation, which consists in transforming the internal form of a word or phrase, or in its complete replacement, to adequately convey the content of the statement.

In the translation process it often becomes impossible to use the matching words and phrases provided by the dictionary. In such cases, we resort to a transformational translation, which consists in transforming the internal form of a word or phrase, or in its complete replacement, to adequately convey the content of the statement. It is difficult to translate the cognitive metaphor, the transfer of "comic" in interlingual communication, since, as it was noted, metaphor is a linguocultural and cognitive-discursive phenomenon, that is, the perception of a cognitive metaphor is different in native speakers and recipients of translation, moreover, the success of the translation of a metaphor depends on individual cognitive features, background knowledge of the translator and the recipient.

\section{BIBLIOGRAPHY}

Aparici R. Cómic y fotonovela en el aula / R. Aparici. - Madrid: Ediciones de la Torre, 1992 . - 378 p.

Barbieri D. Los lenguajes del cómic / D. Barbieri. - Barcelona: Paidós, 1993. - 278 p.

Bobes Naves, M. ${ }^{a}$ C. La semiología / M. ${ }^{a}$ C. Bobes Naves. - Madrid: Síntesis, 1989. - 228 p.

Eco, U. Lector in fabula. La cooperación narrativa en el texto narrativo / U. Eco. - Barcelona: Lumen, 1993 - P. 299.

Carcia, R. El destino de Numancia / R. Carcia - Soria: Numanguerrix, 2018. - P. 57.

Greimas, A. J. y Rastier, F. Las reglas del juego semiótico // A. J. Greimas., F. Rastier / En torno al sentido. - Madrid: Fragua, 1973. - P. 153-183.

Gubern P. El lenguaje del cómic, Actas del seminario de Filología Hispánica: Creación y teoría literaria / P. Gubern. - Logroño: Consejería de Cultura del Gobierno de la Rioja, 1994 - P. 34- 35.

Hjelmslev L. Prolegómenos a una teoría del lenguaje / L. Hjelmslev -Madrid: Gredos, 1980 - 356 p.

Jakobson R. Essais de linguistique générale / R. Jakobson. - París: Éditions de Minuit. 1963 - 556 p.

Jiménez Varea J. El contexto de la historieta: conformación, industria y relación con otros medios». Ámbitos, núm.15, p.191-209. p.192. // Gómez Salamanca / Tebeo, cómic y novela gráfica: la influencia de la novela gráfica en la industria del cómic en España. Barcelona: Universitat Ramon Llul, 2013. - p. 269.

Muñoz-Calvo M., Buesa-Gómez C. Ils sont fous ces traducteurs!: La traducción del humor en los cómics de Astérix y Obélix // M. Muñoz-Calvo, C. Buesa-Gómez. Lengua, traducción, recepción: en honor de Julio César Santoyo, Vol. 1/ coord. por Rosa Rabadán, Marisa Fernández López, Trinidad Guzmán González. - París: Éditions de Minuit, 2010. P. 419-476.

Muro, M.A. Análisis e interpretación del cómic / M.A. Muro. - La Rioja: Universidad de la Rioja, 2004. - 201 p.

Obolenskaya Y, L. Художественный перевод и межкультурная коммуникация / Y. L . Obolenskaya. - M.: Gnozis, 2006 c. 335.

Onieva López, J.L. El cómic online como recurso didáctico en el aula // J. L. Onieva López. Huarte de San Juan, Filología y didáctica de la lengua - Madrid: Espasa-Calpe, 2015. - P. 156-169.

Ortega y Gasset J. España invertebrada / J. Ortega y Gasset - Madrid: Espasa-Calpe, 1984. - P. 56-69

Ramírez Domínguez J. A. El «comic» femenino en España: Arte sub y anulación / J. A. Ramírez Domínguez. - Madrid: Cuadernos para el diálogo, 1975 - P. 19.

Rodríguez Diéguez, J. L. El cómic y su utilización didáctica: Los tebeos en la enseñanza / J. L. Rodríguez Diéguez. - Barcelona: Gustavo Gili 1988, - P. 17-22.

Töpffer R. Essai de physiognomie // R. Aparici Cómic y fotonovela en el aula. Madrid: Ediciones de la Torre, 1992. - P. 19.

Torralba J. Ahí va mi antimanifiesto, de inspiración campbelliana // D. Gómez Salamanca. Tebeo, cómic y novela gráfica: la influencia de la novela gráfica en la industria del cómic en España. Barcelona : Universitat Ramon Llul, 2013. - P. 38.

\section{REFERENCES}

Aparici, R. (1992). Cómic y fotonovela en el aula. Madrid: Ediciones de la Torre.

Barbieri, D. (1993). Los lenguajes del cómic. Barcelona: Paidós.

Bobes Naves, M. ${ }^{a}$ C. (1989). La semiología. Madrid: Síntesis.

Eco, U. (1993). Lector in fabula. La cooperación narrativa en el texto narrativo. Barcelona: Lumen, p. 299.

Carcia R. (2018). El destino de Numancia. Soria: Numanguerrix, p. 57

Greimas, A. J. y Rastier, F. (1973). «Las reglas del juego semiótico», en Greimas. (1976).

En torno al sentido.Madrid: Fragua, pp. 153-183.

Gubern (1994). «El lenguaje del cómic», Actas del seminario de Filología Hispánica: Creación y teoría literaria. Logroño, Consejería de Cultura del Gobierno de la Rioja, p. 34-35.

Hjelmslev, L. (1980). Prolegómenos a una teoría del lenguaje. Madrid: Gredos.

Jakobson (1963). Essais de linguistique générale. París: Éditions de Minuit. 
Jiménez Varea, J. (2006). «El contexto de la historieta: conformación, industria y relación con otros medios». Ámbitos, núm. 15, p. 191-209. p. 192. En Gómez Salamanca. (2013). Tebeo, cómic y novela gráfica: la influencia de la novela gráfica en la industria del cómic en España. Barcelona, Universitat Ramon Llul, p. 269.

Martín, J. (30 de mayo de 2017). Correo electrónico. McCloud, S. (2007): Entender el Cómic. Bilbao, Astiberri.

Muñoz-Calvo, M. y Buesa-Gómez, C. (2010). «Ils sont fous ces traducteurs!: La traducción del humor en los cómics de Astérix y Obélix. Lengua, traducción, recepción: en honor de Julio César Santoyo, Vol. 1 / coord. por Rosa Rabadán, Marisa Fernández López, Trinidad Guzmán González, pp. 419-476.

Muro, M.A. (2004). Análisis e interpretación del cómic. La Rioja: Universidad de la Rioja.

Obolenskaya Y, L. (2006) Художественный перевод и межкультурная коммуникация M.: Gnozis, 335.

Onieva López, J.L. (2015). «El cómic online como recurso didáctico en el aula». En Huarte de San Juan, Filología y didáctica de la lengua, 15.

Ortega y Gasset, José: España invertebrada, Madrid, Espasa-Calpe, 1984. pp. 56-69.

Ramírez Domínguez, J. A. (1975). El «comic» femenino en España: Arte sub y anulación. Madrid. Cuadernos para el diálogo, p. 19. Rodríguez Diéguez, J. L. (1988). El cómic y su utilización didáctica: Los tebeos en la enseñanza. Barcelona: Gustavo Gili, pp. 17-22.

Töpffer, R. (1845). Essai de physiognomie. En Aparici, R. (1992). Cómic y fotonovela en el aula. Madrid: Ediciones de la Torre, p. 19.

Torralba, J. (2010). [«Ahí va mi antimanifiesto, de inspiración campbelliana»]. En Gómez Salamanca, D. (2013). Tebeo, cómic y novela gráfica: la influencia de la novela gráfica en la industria del cómic en España. Barcelona, Universitat Ramon Llul, p. 38.

\begin{abstract}
Анотація
Статтю присвячено аналітичному дослідженню лінгвістичних засобів вербалізації феномена лакунарності та загальним проблеми перекладу лакунарних одиниць у перекладі твору “Доля Нумантіі” з іспанської мови на російську. Розглядено проблеми перекладу пов'язані з явищем лакунарності. Використано функціональні, порівняльні методи, а також метод контекстного аналізу міжмовного та структурно-семантичного порівняння лакунарних одиниць. Дослідження сприяє вивченню міжсеміотичного перекладу коміксів за допомогою описового аналізу перекладу твору «Нумантія» та особливостей іспано-російського перекладу з цілеспрямованими прагматичними функціями. Дослідження здійснюється шляхом ефективного аналізу двох мов та їхніх стосунків при перекладі коміксів російською мовою. Ця робота, що присвячена особливостям міжсеміотичного перекладу, може полегшити роз'яснення оригінального тексту та інших видів перекладу, таких як інтерлінгвістичний або інтерлінгвістичний переклад. Вивчення основних характеристик коміксу як твору окремого жанру здійснено за допомогою корпусу текстів двох мов та взаємовідносин між ними. Основні перекладацькі трансформації було виділено, систематизовано та класифіковано за допомогою наведених з бази фактичного матеріалу прикладів. Обговорюються та розробляються поняття ономотопеї, лакунарності та метафори.
\end{abstract}

\title{
Ключові слова
}

Лакунарність, номінація, семантика, лексична заміна, синтаксична заміна. 